\title{
Land Transport
}

$I^{\mathrm{N}}$ his presidential address on October 15 to the Institute of Fuel (see NATURE, October 31, p. 752), Sir Philip Dawson dealt with the subject of transport on land. The end of the nineteenth century may be called the electrical age, but so far as Great Britain is concerned, since electrical power is mainly produced by steam, its application to traction only means the consumption of fuel transferred from the rolling vehicle to the power-house producing electricity. In countries where electricity can be produced by water-power, this agency may largely affect the total consumption of solid and liquid fuel. Hence the French call water-power la houille blanche (white coal). We are faced to-day with the fact that, despite the high efficiency in producing light, heat and power now obtained in the combustion of coal, the output of coal in Great Britain has diminished from 287 million tons in 1913 to 223 million tons in 1935 .

In 1921, there were 269,000 horse-drawn vehicles on the roads; in 1934 there were only 23,000 . There are now nearly $2,500,000$ vehicles on the road propelled by internal combustion engines. The use of internal combustion engines burning heavy oil has been slowed down by the tax of $8 d$. per gallon imposed on Diesel oil. In Germany the use of this kind of engine is advancing rapidly. The risk of fire and explosion of heavy oil is much smaller than with petrol, and this would be a great advantage in time of war. Transport by road both for passengers and goods is rapidly increasing. This is due mainly to the increased facilities which the road offers both to the passenger and the trader. There were no less than 435,000 goods vehicles employed on the road last year. There are nearly twice as many people employed directly and indirectly in road transport as in railway transport. The motor-spirit and fuel-oil consumed last year exceeded two million tons, and increased by their taxation the revenue of the Govern- ment by forty million pounds. It is estimated that Germany will consume more than two million tons of light synthetic oil this year, more than half of which will be home-produced.

Much could be done in Great Britain to encourage the domestic supplies of petrol by the increased production of benzol by the gas and coke industries. Diesel-electric trains are coming into favour both in Germany and the United States. The great dis. advantage of the steam locomotive as compared with Diesel and electric traction is that it consumes fuel when not actually performing useful work.

The electrification of railways, main line as well as suburban, is constantly increasing throughout the world. In Great Britain, the Southern Railway has made the greatest progress in this direction. All the electricity it uses for traction is supplied by the Grid from steam-operated power plants. Sir Philip quoted with approval the Weir report, which stated that electrification places in the hands of the traffic manager a new system which enables him to offer a more attractive transport proposition to the public and the characteristics of which are capable of extensive development. The adoption of electric haulage for metropolitan and suburban lines nearly always produces increased traffic. The additional cost of the increased train mileage has been much less than the increase in the revenue resulting therefrom. Even in countries where electricity is generated by steam, its largely increased use in industry and for haulage must bring about a decrease in the use of coal in consequence of the greater efficiency realized.

In conclusion, Sir Philip said that every effort must be made in Great Britain to utilize the thermal energy contained in coal for the production of all forms of power, so as no longer to have to rely on fuel imported from overseas, as we have to-day, for operating services which are vital to our national existence and commercial prosperity.

\section{Maya Culture in the Highlands of Guatemala}

$\mathrm{T}$ HE Carnegie Institution of Washington, which under its Section of American Aboriginal History is conducting a comprehensive investigation of the anthropology of Central America, covering the archæology, history under Colonial administration, and physical characters and constitution, linguistics, and social conditions of the modern inhabitants, has undertaken a further investigation in the highland zone of Guatemala. Here a year of mound excavation has already made a substantial advance towards a settled chronological sequence in culture, which is one of the principal aims in present-day archæological research in Central America.

A mound in the noighbourhood of Guatemala city, to be known in future as "Haminaljuya", the "Hills of the Dead", is now being excavated by Dr. A. V. Kidder on behalf of the Institution and at the invitation of the distinguished archæologist, Dr.
Antonio Villacorta, Minister of Public Education, and his son, Sr. Carlos Villacorta, director of the National Museum of Guatemala. This mound is one of a hundred situated within a restricted area of half a mile by one and a half miles. The area, as part of the highland region, is already characteristically known to archæologists as a source of material of the 'archaic' period, for which evidence is also forthcoming from other sites, such as the Valley of Mexico, and from the lowest levels of Uaxactun in the Province of Peten. Certain indications, however, had led Dr. S. K. Lothrop some years ago to infer that remains of a later period might occur in the area, perhaps even so late as the Maya Old Empire; and only last year Dr. Kidder himself, while pointing out that the highland region had served more as a high. way for trade and migration than the lowland jungle country, suggested that its sites might be expected 
to provide extremely valuable information as to the chronological interrelation of the various ancient cultures, particularly as it was probable that stratified remains would be discovered.

These prognostications, it is stated in a preliminary report on the first season's excavation of the mound issued by the Carnegie Institution (Bult., 4, 6), have been strikingly verified. Even so far as operations have proceeded up to the present, it is evident that occupation of the mound was far more prolonged then had been thought probable. The mound presents resemblances to the third of the four sequent stages in the tentative classification of the culture of the lowland eity of Uaxactun, the oldest site yet excavated in the Maya area. This would bring Kaminaljuya at least down to the Old Empire; but finds from the site also present resemblances to those from Teotihuacan, the Toltec city in the Valley of Mexico.

Not only, then, does the evidence of the finds from Kaminaljuya reduce Dr. Lothrop's inference to proved fact, but it also has provided the stratified remains which Dr. Kidder desired. Quite apart, however, from their importance as evidence for cultural sequence, the finds are of an exceptional intrinsic interest. Not the least surprising result of the investigation was that after two pyramids superimposed upon a third had been revealed, still another was found beneath the third. Each of the outer three showed certain differences. The two outer pyramids, for example, rose to a surmounting platform by terraces, the third (reckoning here, as elsewhere, from the interior outward) showing three levels, whereas the second rises steeply in a single slope, and still carries a balustrade of twelve steep steps, while this feature in the third pyramid had been torn away when it was dismantled for the building of the fourth.

In examining the place of the stairway in the third pyramid, three tombs were brought to light; and a fourth, still unexamined, was found under the staircase of the second pyramid. The burials in the three tombs, which have been opened, have produced a wealth of objects, personal ornaments in jade, crystal and other material, pottery, including some remarkable painted ware, obsidian spear-heads, and other funerary offerings, which when more carefully examined at leisure will certainly throw much new light on Maya art, burial customs and culture generally.

The tombs were great square pits, vertically sided, dug in the volcanic deposit, and measuring twelve feet square and twelve feet deep. Originally they were roofed with logs, which, when found, had rotted away and let down stones and earth on the contents. An interesting feature of these tombs is the arrange. ment of the body, which, with attendant circumstances, suggests the interment of a high priest or ruling chief. In the first tomb the personage interred had been placed in a sitting position in the centre of the floor. On three sides of the skeleton lay single human skulls and on the fourth the skull of a jaguar. In the second (Tomb III) the principal skeleton was that of a middle-aged male. The body had again been placed in the middle of the tomb in a sitting posture with the legs crossed. It had been loaded with ornaments, and at the side wos a heap of pottery, in which were two human effigies in clay. At the feet of the skeleton lay the bones of a young woman and vessels for serving food, a milling stone for grinding corn, and other utensils. In a corner were the bones of a small dog. With the principal personage of the third tomb (Tomb II) were two others, possibly slaves. All were in the sitting position, facing south. This was in some ways the richest tomb of all and contained many unique pieces of pottery.

Dr. Kidder suggests in connexion with the burials, basing his opinion upon the evident character of the interment, that the custom of building pyramids superimposed one upon another may have been due to the custom of demolishing the pyramid, of which the deceased had charge at the time of his death, and preparatory to building another for his successor.

\section{Developments in British Telegraph Services}

\begin{abstract}
IN a paper read to the Institution of Electrical Engineers on November 19 by L. H. Harris, E. H. Jolley and F. D. Morrell, details are given of many of the engineering developments which have taken place in the inland telegraph service of the British Isles during the last few years.

It is now clear to engineers that the use of under. ground cables solely for direct current telegraphy is wasteful and that modern developments in amplifiers and filters enable a direct current cable to carry many more circuits. In 1929, the international council (C.C.I.T.) standardized the speed of the teleprinter, and two years later the spacing of the carrier frequencies to be used for voice-frequency telegraph working was also standardized. In 1931 the Post Office installed and operated a London-Dundee 12-channel system, developed and manufactured in Great Britain, which met completely the requirements laid down by the C.C.I.T. A year later the London-Glasgow-Belfast 18-channel system was installed. The introduction of demand telephone
\end{abstract}

trunk working created a shortage of trunk telephone circuits and it was decided to convert practically the whole of the inter-urban telegraph network to voice-frequency working. The telegraph cables thus thrown idle were used for telephone purposes. The number of voice-frequency telegraph channels has doubled during the last three years. The revolution in the methods used in telegraphy has been very thorough. By 1934 scarcely an item of traditional telegraph plant remained in the inland service.

Cable companies, news agencies and newspapers make considerable use of these circuits for speeds up to 100 words per minute. Voice-frequency channels are nearly always used, and even such important circuits as direct extensions of Atlantic cables are employed in this way. An increasing number of newspaper companies now rents telephone circuits on which they provide or rent equipment for alternative speech or pictures and multi-channel voicefrequency telegraphy. 